\title{
13. Mechanisation Outsourcing and Agricultural Productivity for Small Farms: Implications for Rural Land Reform in China
}

\author{
Yu Sheng, Ligang Song and Qing Yi
}

\section{Introduction}

Agricultural productivity in China has experienced a rapid growth over the past four decades. Between 1978 and 2013, agricultural total factor productivity (TFP) grew at an average rate of 2.86 per cent a year, which is more than three times the global average of 0.95 per cent (Fuglie and Rada 2015). The rapid increase in agricultural productivity has lessened the negative effects of constrained supply of inputs (such as land and water) and adverse seasonal conditions, and contributed to a dramatic expansion of agricultural output. Since the late 1970s, the real gross output value of Chinese agriculture has increased by a multiple of 4.6, from US\$129.6 billion in 1978 to US\$594.9 billion in 2013 (in the 2004-06 constant price), with total input increasing by just 66.7 per cent over the same period. Increased agricultural productivity has also released rural labour, facilitating rapid urbanisation and industrialisation in China through rural-urban migration. By 2015, about 270 million rural migrants (around 31.7 per cent of the rural population) moved into Chinese cities, providing an abundant labour supply to support urban industrial development.

While this accomplishment is impressive, agricultural productivity growth in China has more recently hit a bottleneck. Previous challenges have intensified and new challenges have emerged. For example, for decades, overuse of fertiliser and crop chemicals has gradually degraded land and slowed the yield growth of major crops (Zhang et al. 2013; Lu et al. 2015). Furthermore, rising wages and rural labour shortages have increased the cost of agricultural production, which continues to rely primarily on the use of labour-intensive technologies (Huang 2013; Han 2015). A more pressing problem is that falling average farm size (in terms of land area operated) has restricted farmers utilising advanced technologies (such as minimumtillage and no-tillage methods) that are embodied in large plant and machinery (Sheng and Chancellor 2017). Estimates based on annual rural household surveys by the Chinese Ministry of Agriculture show that the average size of farms in China 
declined from 0.73 hectare in the early 1980s to 0.53 ha in 2003 (NBS 1985-2005; Huang and Ding 2016a). As a consequence, growth in selective crop productivity fell between 2005 and 2014: to 70 per cent for wheat, 73 per cent for maize and 51 per cent for barley of the long-term growth rate since 1961 (FAO 2017).

In recognising the importance of sustainable agricultural productivity growth for the realisation of long-term food security, the Chinese Government has, over the past 13 years, initiated a series of institutional reforms to promote the mechanisation of agricultural production and to encourage the adoption of advanced production technologies (Huang and Yang 2017). Major policy changes include a shift from taxing to subsidising agriculture (Tao and Qin 2007; Liu et al. 2012), an increase in public investment in agricultural research and development (R\&D) (Huang and Rozelle 2014; Babu et al. 2016) and gradual market reform and trade liberalisation (Park et al. 2002; Huang and Rozelle 2006; Huang et al. 2009). The most notable change, however, relates to land reforms since 2014 that confirm the property right of land contract' for farmers. The purpose of this reform was to resolve the issue of small farm size, with the new institutional arrangement allowing legal transfer of operational rights to land. This was expected to accelerate land consolidation between medium and small farm operators and thus promote agricultural mechanisation in rural China.

It has been argued in the literature that assisting small landholders to either move up or move out of farming can help to improve industry-level mechanisation and agricultural productivity (e.g. FAO 2015; IFPRI 2015). The underlying assumption is that larger farms have greater willingness and capacity to invest in advanced capital equipment compared with their small counterparts, and thus can realise additional productivity gains through increasing returns to scale and access to new technology embodied in plant and machinery (Sheng et al. 2016). Consolidation of farmland via the market, however, remains challenging, even in developed countries with more transparent procedures and relatively lower transportation costs. This is because of the many market, legislative and institutional barriers that smallholders must overcome, as well as the uncertainties and transaction costs caused by cultural factors and the preferences of small landholders. It is noted that the issue of small farm size extends far beyond China: in 2012 more than 50 per cent of farms in the United States were categorised as small, defined as those having sales value and operational land scale below the bottom 20 per cent of the average (Key 2017). Identification of alternative ways to solve small-scale farming efficiency challenges is of broader public interest, especially for China, where more than 50 per cent of farms operate on less than 1 ha of land.

This chapter explores institutional innovation arising from the recent development of capital markets (namely, capital outsourcing) and the related potential for promoting the agricultural mechanisation of small farms in China. We argue that, under certain institutional arrangements, contract mechanisation services (in particular, capital outsourcing) can substitute for farmers' own investment in 
plant and machinery. This, in turn, can improve the capital-labour ratio of medium and small farms, complementing previous land consolidation reform in China to improve industry-level agricultural productivity. To justify this argument, we analyse the trend of industry-level agricultural productivity in China since 1978 and link this to agricultural capital equipment and average farm size, investigating the interaction between land reform and contract mechanisation services and their impact on farm productivity. Our discussion provides indirect evidence that, under certain conditions, small household farms can significantly increase their capital-labour ratio in production through contracting in mechanisation services. Without incurring the sunk costs related to investment in expensive yet efficient capital equipment, these small farms are now able to explore the productivity benefits from increasing returns to scale and adopting new technology. Moreover, contract mechanisation services can also facilitate land consolidation and change the way in which small farms optimise their production procedures. This provides useful insights for China and other countries attempting to improve agricultural productivity of their small household farms.

The remainder of the chapter is organised as follows. Section two describes the trend of agricultural productivity growth in China over the past three decades and links recent stagnation in productivity growth to the small size of a large share of China's household farms. Section three discusses historical land reforms and their impact on farm size in rural China, and raises the question of whether allowing 'land contract rights' to be legally transferred through markets could facilitate long-term land consolidation and productivity growth for small farms. Section four analyses the development of contract mechanisation services, their potential role in substituting for farmers' own investment in plant and machinery and their impact on levels of industry mechanisation. Section five reviews the literature exploring the impact of contract mechanisation services on farm size and household production in China, and points to its potential role in resolving the issue of small farm size. Section six provides the conclusion.

\section{Agricultural productivity, capital investment and small-farm issues}

Agricultural productivity in China grew rapidly after the household responsibility system (HRS) reform in 1978. As an institutional innovation to solve incentive problems inherent in the collective production system under people's communes, the HRS significantly raised agricultural productivity through contracting cultivated land to farm households in each village (Huang and Yang 2017). Compared with the pre-reform period of 1961-78, when agricultural TFP rose by a mere 0.66 per cent a year, the growth rate increased by a multiple of more than 4 per cent per annum, to 3.08 per cent annually, during the early 
reform years, $1979-84$, and by 2.95 per cent a year during the later reform period, 1985-2013 (Figure 13.1). Over the period 1961-2013, the growth of agricultural TFP contributed more than half of China's annual real output growth (4.3 per cent) — a rate that was much higher than those of most developed and developing countries (Figure 13.2). ${ }^{1}$

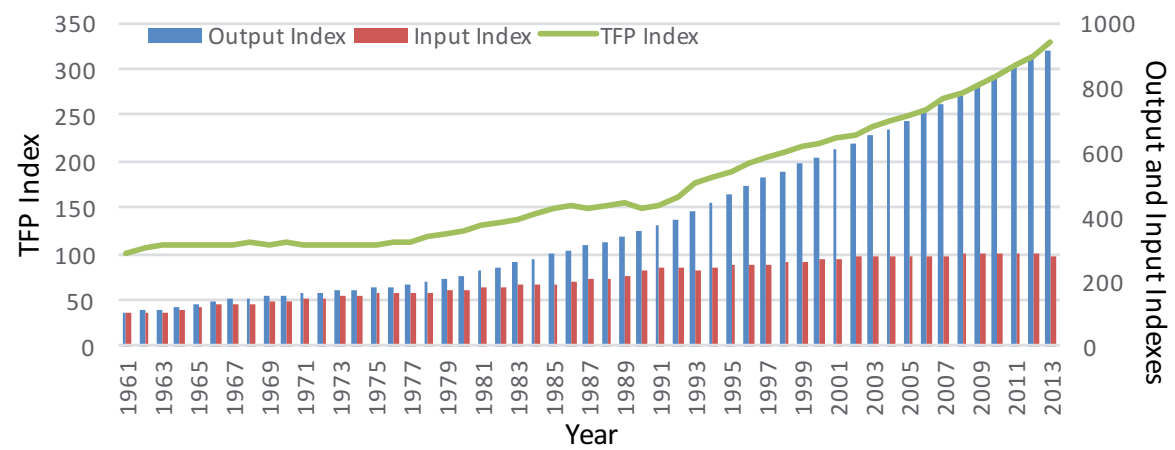

Figure 13.1 Output, input and TFP index in Chinese agriculture, 1961-2013 Source: Authors' estimates based on data from Fuglie and Rada (2015).

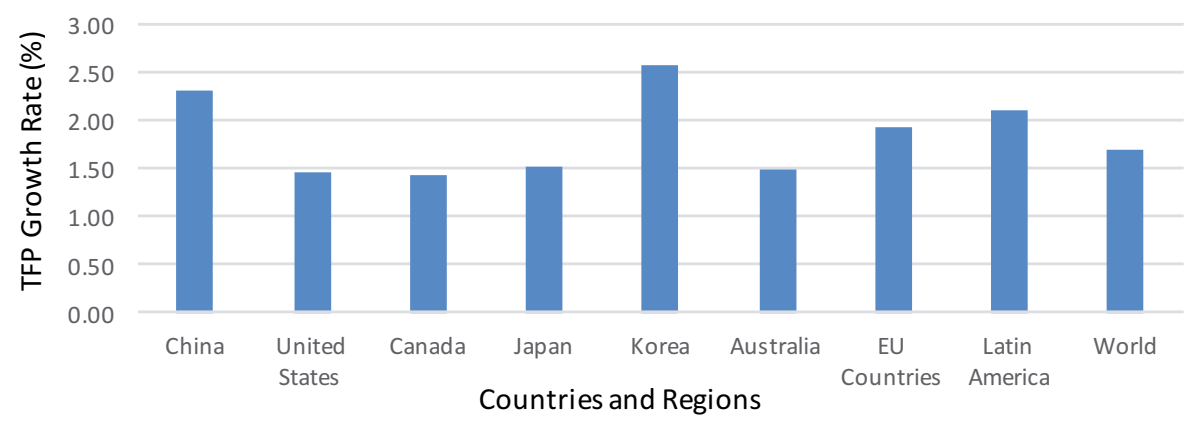

Figure 13.2 Comparison of agricultural TFP growth in China and the rest of the world, 1961-2013

Source: Authors' estimates based on data from Sheng and Song (2017).

Underlying this rapid productivity growth is a dramatic change in the structure of agricultural output and input. Between 1989 and 2014, real total agricultural output in China increased from US $\$ 129.6$ billion to US\$594.9 billion (at the 2004-06 constant price) - an annual growth rate of 4.5 per cent. The proportion of cereals in total agricultural output, however, has declined, from 33.6 per cent to 23.5 per cent. The proportion of vegetables, fruits and nuts, on the other hand, increased, from

1 Note that the comparison of agricultural TFP between countries needs to be approached with some caution because developing countries such as China, Korea and those in Latin America have come from a low base since 1961 compared with the United States, Canada and Australia, which have had access to capital for some time and have operated within very different regulatory and market environments. 
8.2 per cent to 19.2 per cent, as did the proportion of livestock and meat products in total agricultural output, from 25.6 per cent to 29.3 per cent. The shift in agricultural production towards higher-value and higher-protein products in particular reflects dramatic improvement in the production efficiency of coarse grains relative to other products, and was partly driven by changing food demand. On the input side, both capital and intermediate inputs increased significantly, substituting for land and labour in production. Between 1978 and 2014, real total inputs into agriculture in China have grown at the rate of 1.58 per cent a year; machinery units (measured by using the number of 40 -horsepower tractor equivalents) and fertiliser usage grew at the rate of 6.23 per cent a year and 4.19 per cent a year, respectively. The latter helped to compensate for the decline in labour usage $(-0.6$ per cent a year) and a mild increase in land usage ( 0.56 per cent a year) (Figure 13.3).

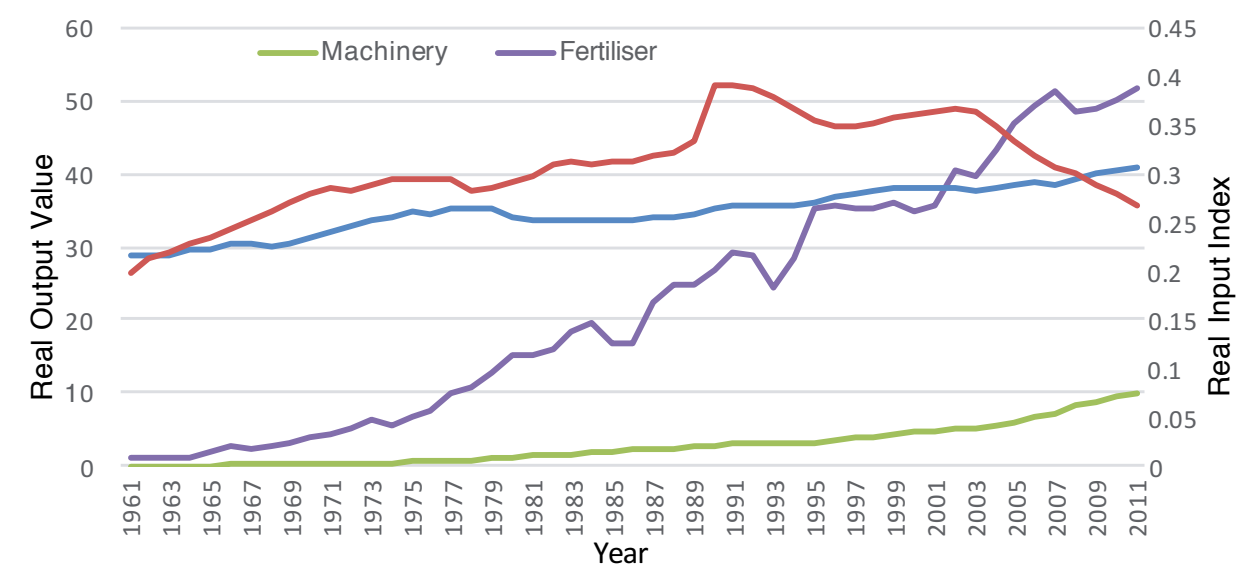

Figure 13.3 Change in input components of agricultural production (US\$ million at 2004-06 price)

Source: Authors' estimates based on data from Fuglie and Rada (2015).

At the industry end, it is widely believed that agricultural productivity growth and input-output structural adjustment in China were driven by ongoing technological progress and its diffusion between farms (Huang and Yang 2017). In the technology diffusion process, increasing investment in new plant and machinery is regarded as an essential channel through which farm households improve their level of mechanisation and gain access to the embodied technology. Between 1978 and 2013, the power of plant and machinery per capita in agricultural production increased from 3.5 kilowatts $(\mathrm{kW})$ to $44.7 \mathrm{~kW}$, with an annual growth rate of 6 per cent a year (MOA various issues). Using capital equipment to replace labour has allowed farms not only to increase the efficiency of some primary inputs such as land and labour, but also to expand their TFP and profitability. As such, a strong positive relationship is observed between industry-level agricultural productivity (i.e. yield, labour productivity and TFP) and capital equipment per capita over the past three decades (Figure 13.4). 


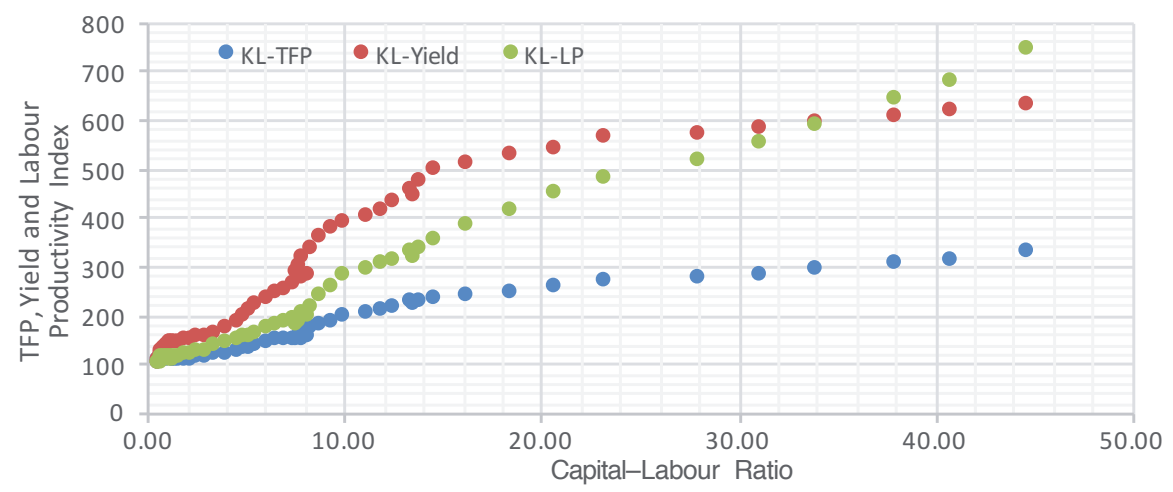

Figure 13.4 Relationship between the capital-labour ratio and agricultural productivity, 1961-2013

Source: Authors' estimates based on data from Fuglie and Rada (2015).

Although the capital-labour ratio in Chinese agriculture has significantly increased over time, it is still much lower than that in developed countries such as the United States, the European Union (EU), Australia and Japan (Figure 13.5). In 2013, China's level of capital equipment per capita in agriculture was only one-twentieth that of Australia, one-forty-seventh of the United States and one-seventy-sixth of that in Japan (Fuglie and Rada 2015). In addition, a majority of the plant and equipment (more than 85 per cent) used in China's agricultural production was smaller and less efficient than that used in developed countries (MOA various years). This relatively low capital-labour ratio and inferior capital equipment prevented Chinese agriculture from further improving its industry-level productivity. A critical issue for policymakers, therefore, is to encourage investment in agricultural capital equipment so as to improve the level of mechanisation in agricultural production.

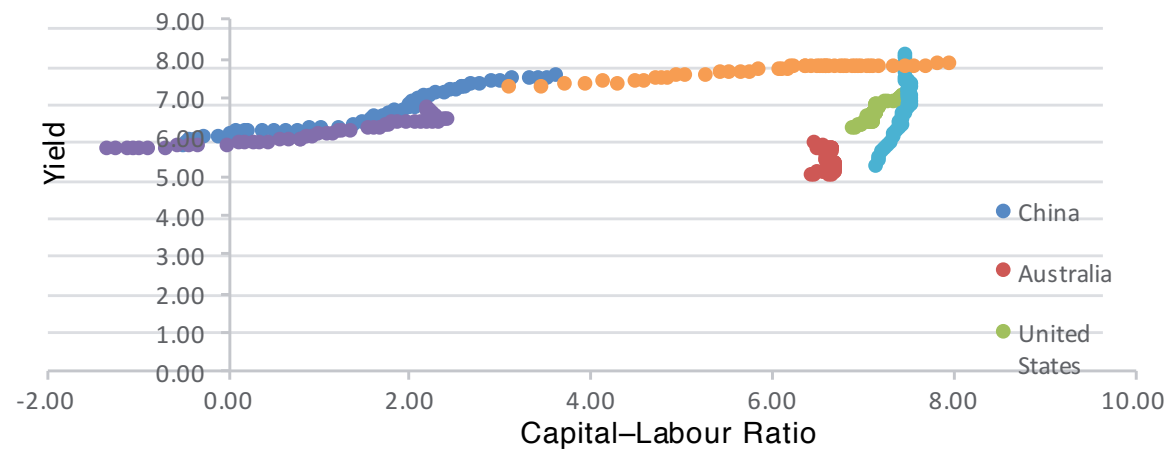

Figure 13.5 Relationship between logarithm of yield and capital-labour ratio between countries, 1961-2013

Source: Authors' estimates based on data from Fuglie and Rada (2015). 
Theoretically, large farms have a higher propensity to invest in larger and more advanced equipment than their smaller counterparts. This is not only due to lower budget constraints for capital investment, but also because the average sunk costs of capital investment will decline as output increases. The willingness and ability of small farms to make capital investment are, in contrast, restricted by their lesser financial capacity and limited scope for increasing returns to scale and obtaining gains from adopting new technologies. This logic applies even more so when increased R\&D costs result in more expensive and more efficient new capital equipment over time.

In China, agricultural production is based on farming households tending to a small piece of land that is rented from the local rural community. The average size of Chinese household farms is less than 1 ha (just less than 40 per cent of the global average for small farms), and, moreover, until 2004, was in continual decline (Huang and Ding 2016a). While a number of exceptionally small farms are able to achieve high productivity, the majority rely on intensive use of self-employed labour as a substitute for capital. Moreover, much of what capital plant and machinery is used in production is outdated and inefficient. This constrains the industry from improving mechanisation levels and from realising higher levels of productivity growth. To eliminate these obstacles to agricultural mechanisation and productivity growth, it is essential to resolve the investment problem related to small farm size.

\section{Land policy, farm consolidation and transformation}

In the agricultural development literature, the effect of farm size (i.e. land size) on agricultural capital investment and productivity has long been debated. Many studies have found an inverse relationship between farm size and productivity in developing countries, including in India, Vietnam and some African countries (i.e. Sen 1962, 1966; Lipton 1993; Dyer 1996; Deininger and Byerlee 2012). There is also evidence that small may not necessarily be beautiful, especially when ongoing technological progress changes methods of agricultural production and management. For example, small farms may face increasing challenges in meeting the structural change of agricultural demand and may also be reluctant to make related capital investments in newly developed production technology (Hazell 2005; Huang et al. 2008). Small farms also lack the capacity to cope with opportunities and risks arising from volatile market and climatic conditions (HLPE 2013). To deal with these issues, a general consensus among economists and policymakers is to transform small farms into large farms (or consolidate agricultural industry) by assisting small farms either to move up or to move out of the farming sector (IFPRI 2015; FAO 2017). 
Although the principal need to resolve the challenges of small farms is clear, it is difficult to implement in practice, especially in developing countries where agricultural product and factor markets are usually incomplete. In China, the transformation of small farms is constrained especially by the way in which agricultural land is allocated through leasing and related institutional arrangements. Initiated by the HRS in 1978, cultivated land has been contracted to individual households in each village based on the number of people and/or units of labour in the household (equity). As an institutional innovation to resolve incentive problems inherent in the previous collective production system under people's communes, the HRS succeeded in raising agricultural productivity in the early reform period (1978-84), but it also shifted land-use rights from a collective-based system to a family-based one. Since land-use rights (which are separate from landownership) are not transferable after initial allocation, the average operational scale of farms is constrained by the amount of land initially allocated to each household. An estimate based on rural household surveys showed that the average size of farms in China was 0.73 ha in the early 1980s (NBS 1985-2005), which declined to 0.61 ha until 2013.

Another feature of the land reforms introduced in 1978 that affected the operational scale of farms and farmers' decisions about capital investment relates to the insecure tenure of land contracts. In the early 1980s, land contracts lasted for only three years or less. The short duration of land contracts offered no confidence or incentives for farm operators to make long-term production and investment plans. To improve security of tenure, a new policy was proposed in 1984 to increase the contract duration to 15 years, although it was 'never seriously publicized or implemented' (Zhu and Prosterman 2007). In 1993, the central government issued a further directive, which extended land contracts to a continuous and fixed term of 30 years. However, this new term was not embodied in formal law until 1998, when the government also initiated a massive campaign to publicise the policy (Zhao 2015). These policies generally did little to change farmers' incentives for investment, since village officials (the government) held the privilege (under the regulation) to periodically redistribute land among households in the middle of these fixed terms (Kung and Liu 1997; O’Brien and Li 1999; Pastor and Tan 2000).

Throughout the 1980s and 1990s, a majority of rural land was reallocated by village leaders using administrative methods, although the frequency of land reallocations varied between villages (Brandt et al. 2002; Krusekopf 2002). According to surveys conducted in the 1990s, by 1996, two-thirds of Chinese villages had reallocated land using administrative methods, often in the middle of land contract terms (Brandt et al. 2002). By 2002, 207 of 244 villages in the Ministry of Agriculture's National Fixed-point Survey (NFS) had reallocated land, and the average number of reallocations each village conducted between 1980 and 2002 is two (Zhao 2015). While the exact procedure by which land is redistributed differs between villages 
(Figure 13.6), the most common practice is for village leaders to redivide all village land into bundles with equal distribution of land-quality types, and to distribute the bundles to households based on their population and agricultural labour force. Since land redistribution does not necessarily reflect land-use efficiency, but rather seeks to maintain a relatively egalitarian distribution of land, the average operational scale and land size of farms over the period have declined. By 2003, average land areas operated per farm had decreased to $0.53 \mathrm{ha}$, which was 72.6 per cent of that in 1980 (NBS 1985-2005).

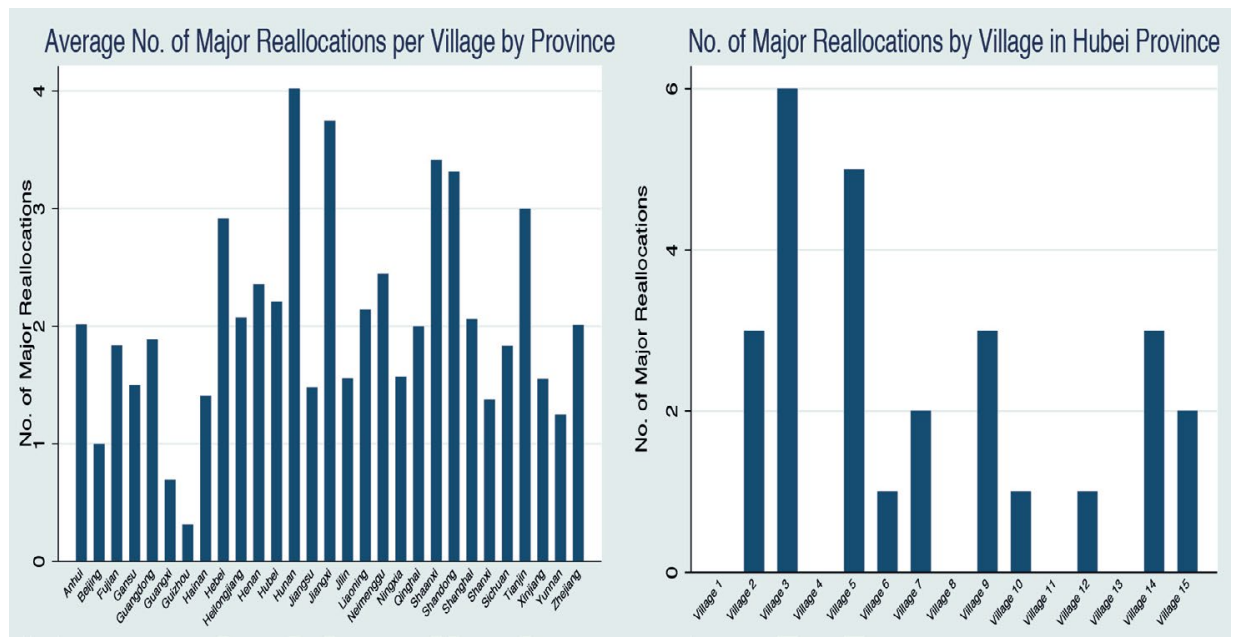

Figure 13.6 Variations in instances of land reallocation

Source: Zhao (2015).

In 2003, the National People's Congress decided to enact the Rural Land Contracting Law (RLCL) with the aim of improving security of tenure. Differing from previous laws, the RLCL was devoted entirely to clarifying the relationship between collective landownership and farmers' use of land, and enforced the contractual arrangements between the two parties (Prosterman et al. 2006). In particular, it explicitly prohibited land reallocation by village officials throughout farmers' 30-year terms of land usage. The frequency of land reallocations has since significantly decreased. On average, only 2 per cent of villages conducted annual reallocations between 2003 and 2006, compared with a yearly average of about 9 per cent before 2003 (Zhao 2015). However, the RLCL still did not allow farm households to exchange land-use contracts via the market. Therefore, the reform helped to improve the security of tenure of land contracts under the HRS, but did not facilitate land transfers between households or land consolidation within China's agricultural industry. 
From 2000, China's urbanisation process accelerated, with more and more rural migrants driven to the cities by the prospect of higher wages. By 2010, around 160 million rural migrants had moved into urban regions in China (Meng and Zhang 2010) and the proportion of labour in agriculture decreased from 49.1 per cent in 2003 to 31.4 per cent in 2013 (NBS 1978-2014). The rapid decline in the rural labour supply raised the returns to labour relative to the amount of land in agricultural production, but did not proportionally increase farm size because of the current arrangements for land allocation. Between 2003 and 2013, the relative productivity of labour to land increased by 66.3 per cent, while the average farm size (measured by land area per household) increased by only 15.1 per cent (Figure 13.7). Although land transfers have accelerated since 2000, most of these were between relatives and friends within a village (Huang et al. 2012). By the end of 2013, some 53 million (23 per cent) rural households had rented out their land, accounting for 26 per cent of total agricultural land under the HRS (MOA 2014). However, average farm size remained at 0.61 ha per farm for rural households and 0.78 ha for all agricultural business (Huang and Ding 2016a). This farm size remained too small to benefit from the productivity gains available from the use of larger and more efficient capital equipment.

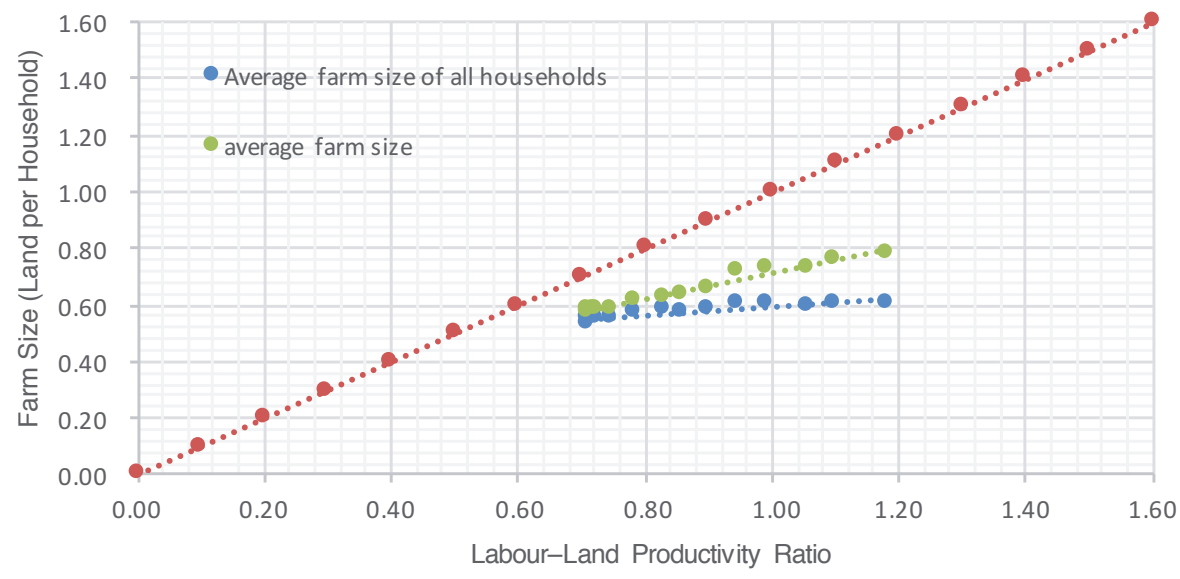

Figure 13.7 Relationship between relative labour-land productivity and farm size, 2000-13

Notes: The share of cultivated land per household is 93 per cent of the total land. The estimates of farm size exclude those households whose members remained in rural areas but were fully engaged in non-farm rural employment.

Source: Authors' estimates based on data from NBS (1978-2014).

Finally, in terms of the distribution of farm size, a majority of farm households operate on a small piece of land, although there appears to be rapid growth in medium and large-scale farms. By the end of 2013, the share of farm households operating on more than 70 ha of land in the total number of farms in northeast and northern China (where average farm size is 1.73 ha, around three times the national average) was still less than 0.02 per cent. Based on estimates using 
a farm operations survey by the Center for Chinese Agricultural Policy (CCAP) at the Peking University, more than 90 per cent of farm households in north-east and northern China operated on less than $3 \mathrm{ha}$, among which around two-thirds operated on less than 1 ha (Figure 13.8).

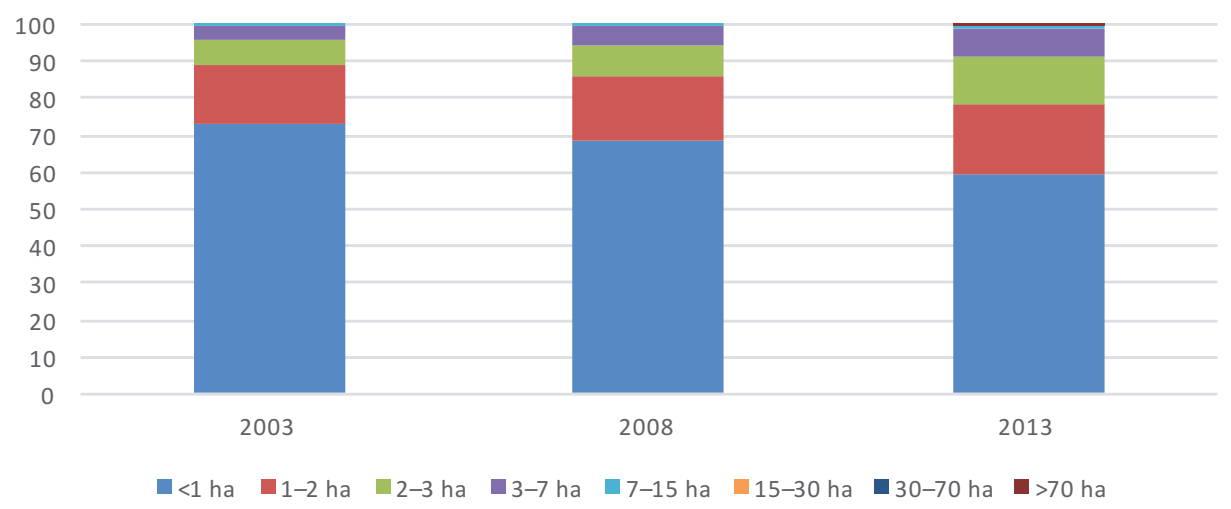

Figure 13.8 Distribution of farm size (by land area) in north-east and northern China: 2003, 2008 and 2013

Source: Authors' estimates based on data from Huang and Ding (2016a).

To encourage land transfers between farm households to improve land consolidation, in 2015 China's State Council amended the national Land Law by formally separating land operation rights from land contract rights. The directive, for the first time, allowed land contract rights to be legally transferred through market mechanisms. Following the directive, a series of institutional innovations-including establishing land transfer service centres to promote land rental and policy support for land consolidationhas been developed to assist small farms to enlarge their operational scale through market transactions (Huang and Ding 2016a). Over time, this kind of institutional arrangement will gradually support land contract consolidation among those farmers who decide to stay in farming and will also improve land distribution and land-use efficiency. This is, however, dependent on whether market failure in the transformation of farm operations (such as high land transaction costs; as in Kimura et al. 2011) can be dealt with appropriately. It is recognised that achieving land consolidation via market transactions that produce larger farming operations, which in turn utilise heavy plant and machinery, is a process that may require more time.

\section{Agricultural mechanisation and contracting capital services}

As discussed in section three, land transformation and consolidation can help to improve farm productivity by changing the willingness of household farms to make capital investment. When farms operate on a relatively larger piece of land 
(or become larger), they are more willing and able to pay the sunk costs for capital investment, and thus can benefit from increasing returns to scale and advanced technology embodied in new plant and machinery. Moreover, the larger the farm size, the higher will be the mechanisation level and productivity. If the literature (i.e. Sheng et al. 2016; Foster and Rosenzweig 2017) proposing this connection is correct, the positive relationship between farm size and productivity can also be interpreted as a consequence of market failure or a mismatch in capital markets due to the non-divisible capital supply, and cannot be accessed by a large number of individual small landholders (or farms).

Although enlarging farm size can moderate this problem, the mismatch between the capital demand of small household farms and capital supply from industrialised production can still exist, and even tends to rise over time as ongoing technological progress makes advanced capital equipment more efficient but also more expensive. To resolve this conflict, institutional innovation in outsourcing capital services may offer a more efficient solution than land consolidation. Specifically, a marketbased capital service provider can pool the demand for mechanisation services from individual small farms, and raise funding to purchase the corresponding equipment, matching demand with the capital supplier. Via this process, each party minimises their costs, and farms of different size will gain access to the same capital equipment and embodied technology without incurring the associated large financial outlays that would otherwise be required to individually purchase capital equipment. When market-based contracting of mechanisation services becomes a close substitute for individual farmer's investment in plant and equipment, small farms might be expected to catch up with their larger counterparts in terms of productivity. This implies that using market-based mechanisation services to substitute for individual farm-level investment could be an alternative and more effective way to improve the capital-labour ratio and productivity of small household farms.

For decades after the process of opening up and reform began in 1978, the adoption of advanced production technology (measured using the mechanisation level of agricultural production) in China was positively correlated with levels of per capita capital equipment. Between 1980 and 1990, the mechanisation level of agricultural production stayed at a relatively low level, with the proportions of farmland ploughed, sown and harvested using machinery around 28.8 per cent, 9.4 per cent and 5.4 per cent, respectively (Figure 13.9). This can be attributed to the fact that agricultural production over that period relied on labour-intensive technology. As more and more rural labour moved to urban areas, a rapid increase in agricultural investment raised the capital-labour ratio and improved the mechanisation level of agricultural production in China. Throughout the period 1990-2003, the numbers of tractors, attached equipment and total machinery power per capita increased by two times, four times and 90 per cent, respectively (Figure 13.10). As a consequence, the mechanisation level of agricultural production-measured using the proportion of farmland mechanically ploughed, sown and harvested-more than doubled 
by 2003. From 2003, the mechanisation level of agricultural production in China increased more quickly, as per capita capital equipment accelerated, with a further increase in capital investment and a decline in rural labour supply. By 2014, more than half of all cultivated land was mechanically sown and harvested and around 80 per cent was mechanically ploughed.

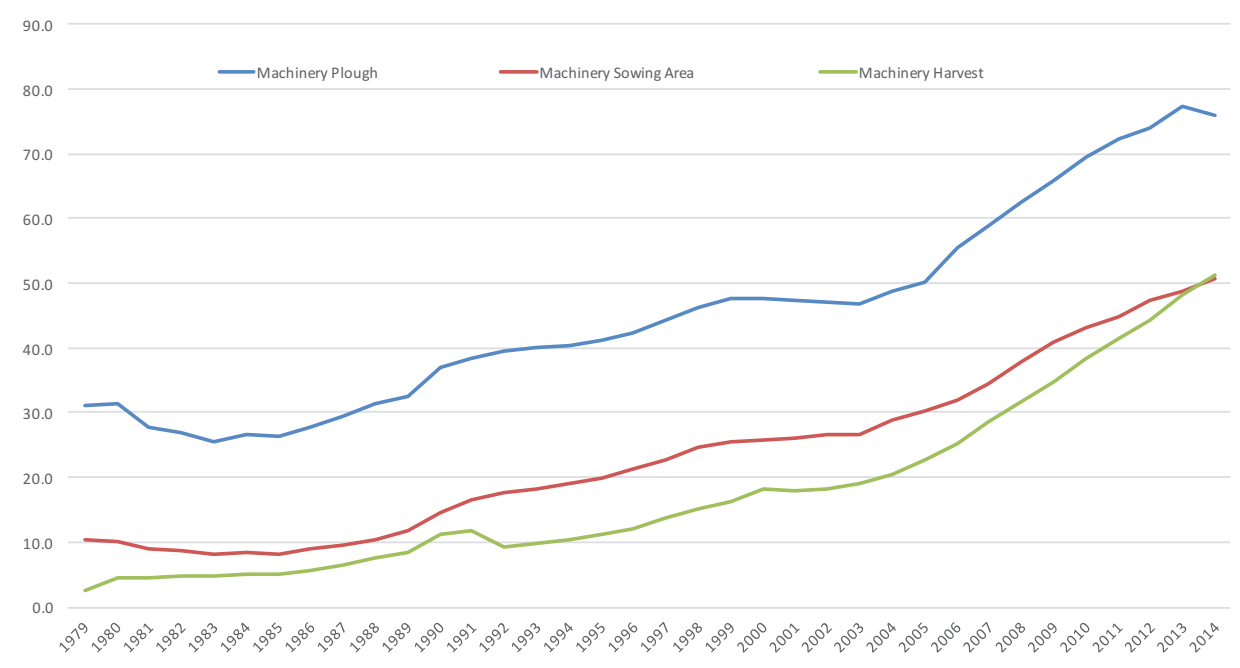

Figure 13.9 Farmland ploughed, sown and harvested using machinery, 1979-2013 (per cent)

Source: Authors' estimates based on data from NBS (1978-2014).

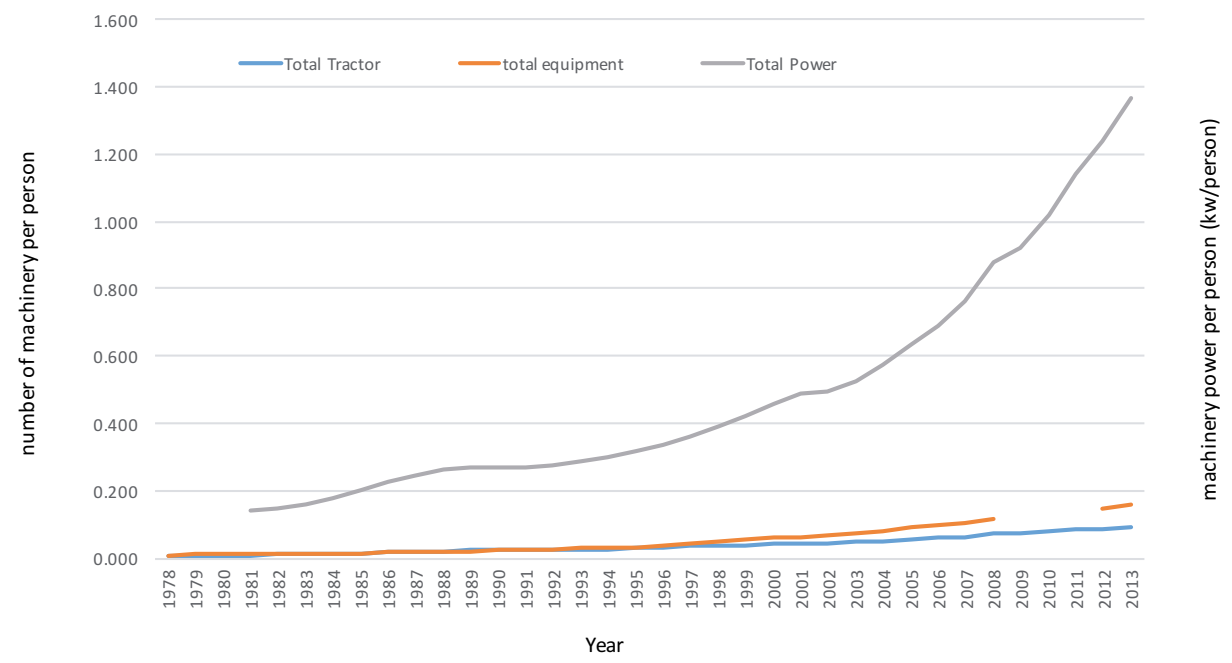

Figure 13.10 Agricultural tractors, attached equipment and total machinery power per capita in China, 1978-2014

Source: Authors' estimates based on data from NBS (1978-2014). 
Although the capital-labour ratio in agricultural production has been increasing since the 1980s, the structure of capital equipment (in terms of its per-unit size) has changed over time alongside farm size. Between 1980 and 2003, the share of total engine power of large tractors in total engine power declined from 60 per cent to 20 per cent, while average farm size declined from 0.73 ha to 0.53 ha (Figures $13.11 \mathrm{a}-\mathrm{b}$ and 13.12). Over this period, the increase in total capital equipment came mainly from increased investment in small tractors and equipment (Figures 13.11a and 13.11b). When average farm size began to increase after 2003, however, the total amount and proportion of large tractors and attached equipment also started to increase. Growth in the use of small tractors and attached equipment, however, began to slow after 2010, implying that the growth in use of large tractors and attached equipment had by then become a driver of growth of total capital equipment. This, in turn, implies that the capital structure of agricultural production in China has, since around 2010, been characterised increasingly by larger plant and equipment as farm size increases, suggesting an increase in capital efficiency (since larger machinery is typically more efficient).

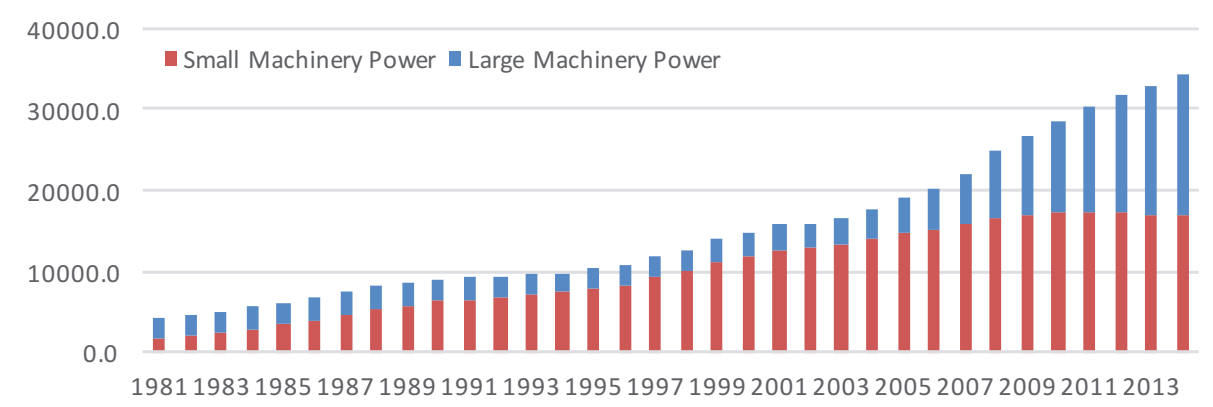

Figure 13.11a Engine power of large tractors and equipment in use, by size: 1978-2014 (billion watts)

Source: Authors' estimates based on data from NBS (1978-2014).

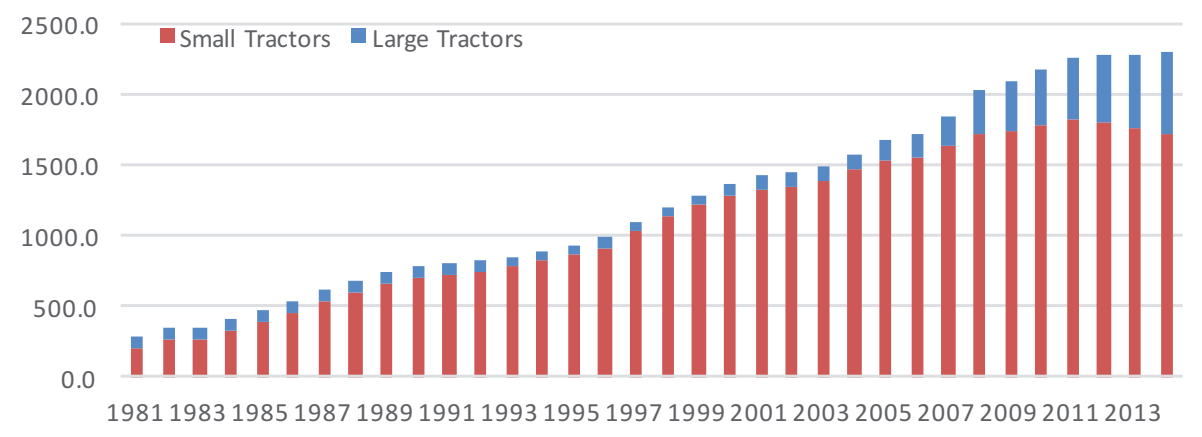

Figure 13.11b Total agricultural machinery in use, by size: 1978-2014 (million) Source: Authors' estimates based on data from NBS (1978-2014). 


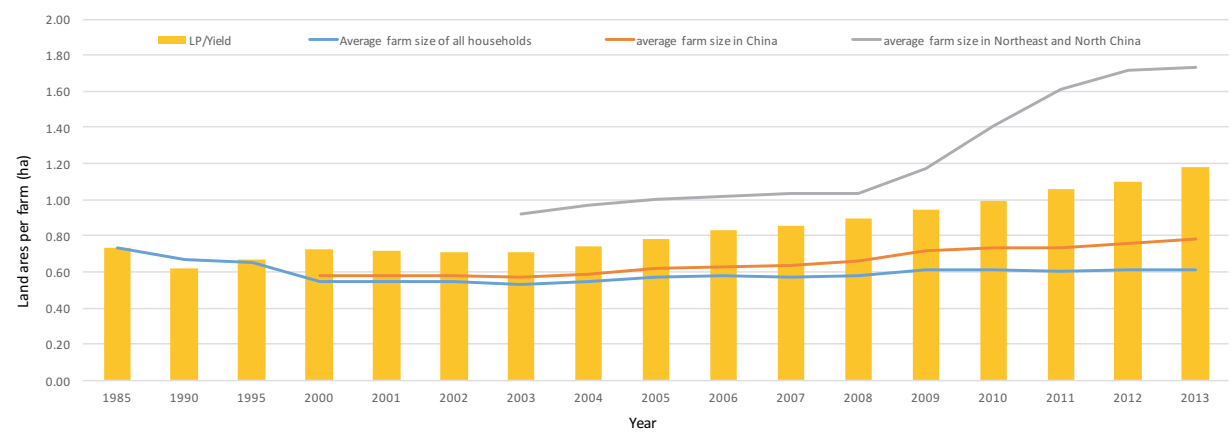

Figure 13.12 Average farm size in China, 1985-2013

Source: Authors' estimates based on data from Huang and Ding (2016b).

In addition to increased farm size, another important factor contributing to the shift in capital structure in China's agricultural production towards large and more efficient plant and equipment after 2003 is rapid development of rural socialisation services (mainly mechanisation services). ${ }^{2}$ Between 2008 and 2013, the total number of communities that provided mechanisation services to farm households increased from 8,600 to 42,000 — an annual growth rate of 37.2 per cent (Figure 13.13). At the farm level, there were 168,600 professional agencies that provided mechanisation services to farm households in rural China, and more than 12.4 per cent of farm households ( 5.24 million of 42.4 million) that owned large plant and machinery provided mechanisation services to the market by 2013 . This generated total revenue of RMB510.8 billion and total profit of RMB195.6 billion that year. The rapid development of a contract market for capital equipment-related services not only enabled small household farms to access the capital services of large plant and equipment as their large counterparts increased their productivity, but also incentivised capital equipment holders to invest further in large plant and machinery. As a consequence, the relative demand for large and efficient tractors and equipment compared with small and less efficient ones increased rapidly over time.

2 It is also argued that government subsidies for large plant and equipment are another important driver of investment in large plant and machinery (He et al. 2010). 


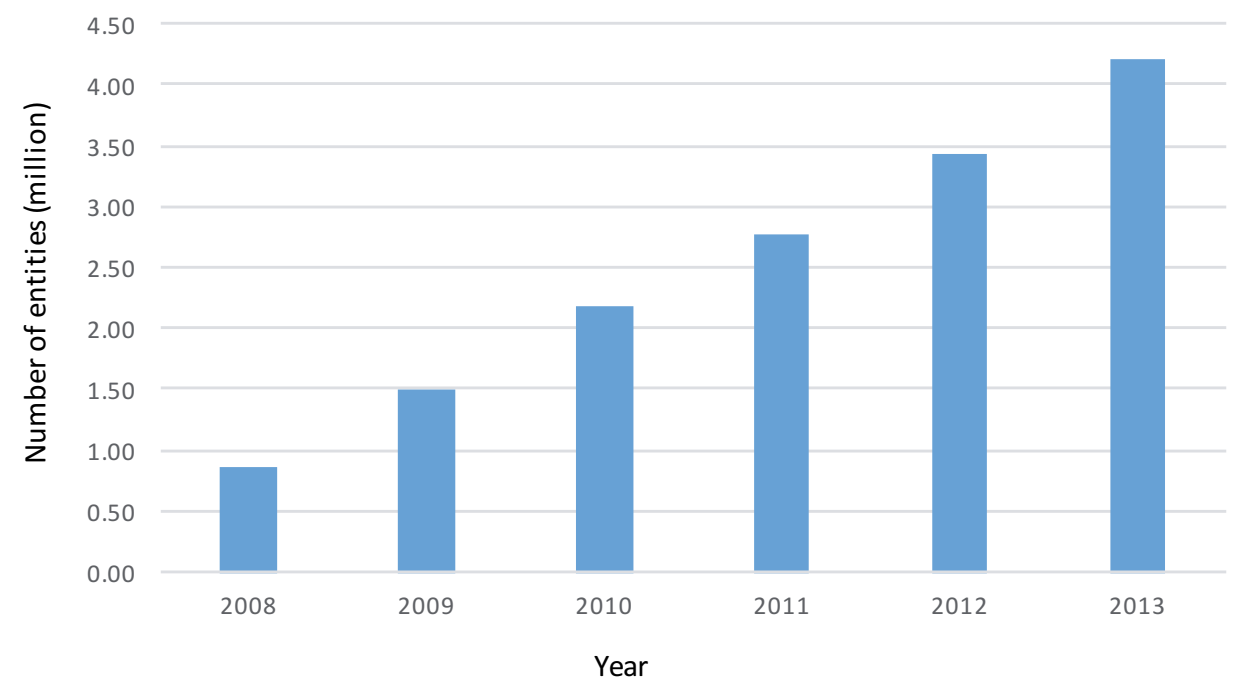

Figure 13.13 The number of communities providing mechanisation services in China, 2008-13

Source: Authors' estimates based on data from NBS (1978-2014).

Although contracted mechanisation services have gradually become an important channel for the promotion of agricultural production mechanisation in China, their impact on total demand for and supply of agricultural capital equipment remains negligible. This is mainly because both land consolidation and average farm size are restricted by high land transaction costs resulting from existing institutional arrangements. In particular, the proportion of market-based contract mechanisation services in total contract mechanisation services is small. By 2013, the total number of market-based contract mechanisation service providers accounted for less than 0.4 per cent of the total number of mechanisation service providers $(168,600$ out of 425.6 million), among which less than 20 per cent were large machinery holders (with current value of plant and machinery of more than RMB500,000) (Figure 13.14). Increased policy support from the central government since 2014, however, is expected to double the total number of market-based contract mechanisation service providers by 2020 (MOA 2014). Yet, there is still a long way to go before such market-based services can play an important role in substituting for farm-level investment. 


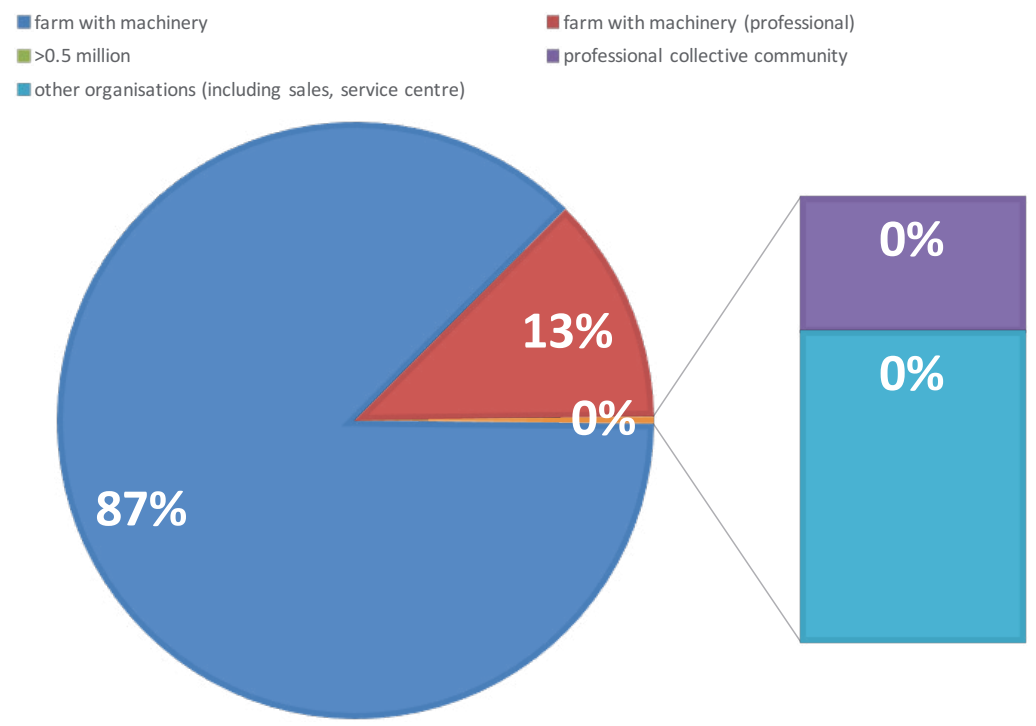

Figure 13.14 Structure of contract mechanisation services, 2013

Source: Authors' estimates based on data from NBS (1978-2014).

\section{Land consolidation and contract mechanisation services: Piece up together}

Although land consolidation and contract mechanisation services may help to resolve some of the challenges presented by small-scale farming in China, they are only in a preliminary stage of development, providing different prescriptions for and mechanisms by which to effect on-farm capital equipment use and therefore productivity. Two questions thus arise: 1) Which is more efficientland consolidation or contract mechanisation services? 2) What is the relationship between land consolidation and contract mechanisation services? To answer these questions, we review three groups of existing studies that analyse the farm sizeproductivity relationship and its underlying determinants in China, and use findings from these studies to shed light on this issue.

The first body of literature examines the relationship between farm size (in particular, land size) and productivity, which provides useful information to understand the relative contribution of land consolidation to solving small farm-related challenges. Following the literature examining the inverse relationship between farm size and productivity (Assuncao and Ghatak 2003; Deininger and Byerlee 2012), Chen et al. (2010) examine the relationship between farm size and productivity in China using farm-level household survey data between 1995 and 1999. Their study found 
that total farm output in China declined with cultivated land area, and this could be attributed to local administrative land distribution policies, uneven off-farm work opportunities and heterogeneity in land quality. More recently, Huang and Ding (2016b) re-examined the relationship between farm size and productivity by using farm-level and paddock-level data for the grain industry in north-east and northern China between 2003 and 2013. They provided some evidence of an inverse-Ushaped relationship between farm size and the yield or profitability of the rice, wheat and maize industries in China over the past decade (Figures 13.15 and 13.16), with the optimum land size per farm being $7-15$ ha.

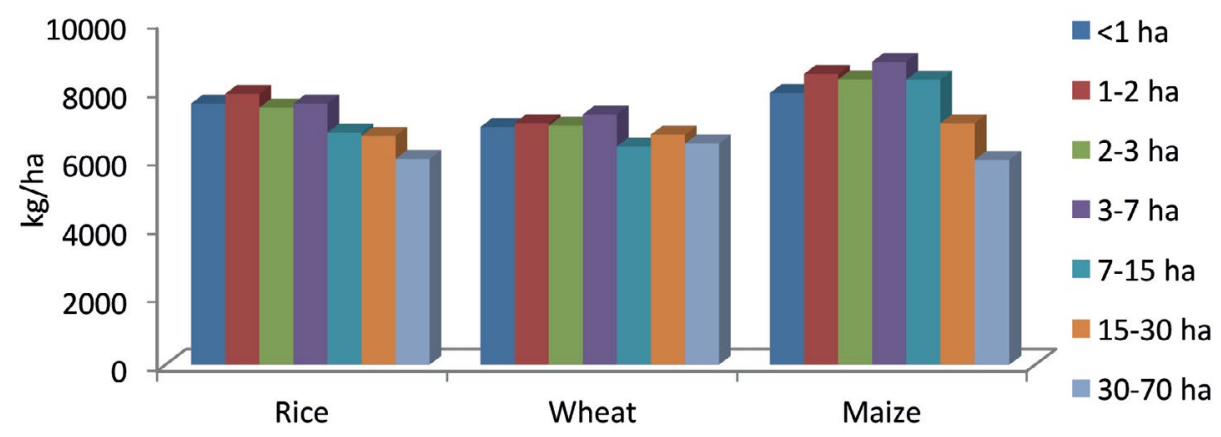

Figure 13.15 Farm size-crop productivity in China, 2013 (hectares) Source: Huang and Ding (2016b).

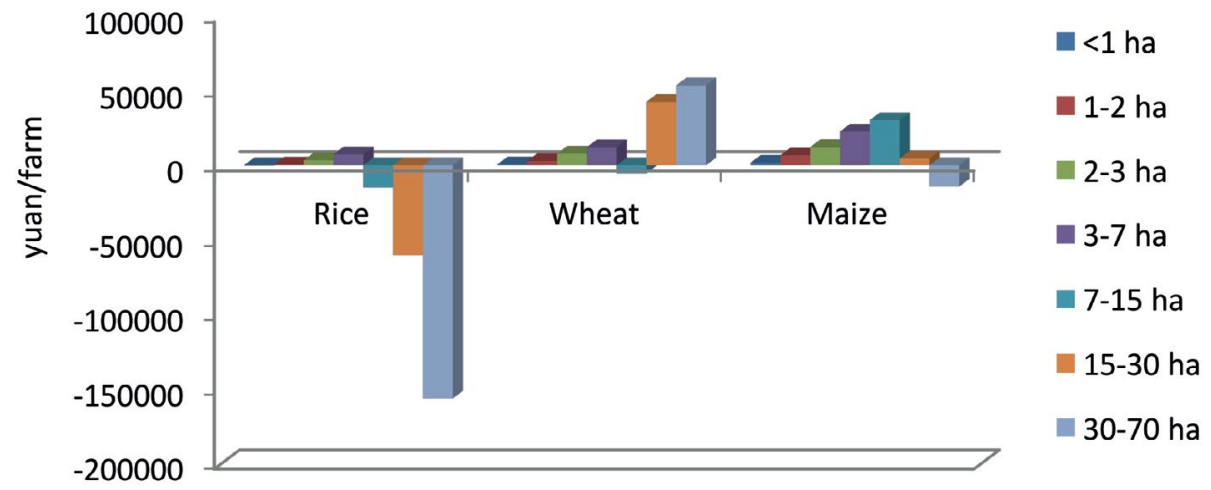

Figure 13.16 Farm size-profitability relationship in China Source: Huang and Ding (2016b).

Findings from empirical studies examining the farm size-productivity relationship generally suggest that small household farms in China may not benefit from continuing to enlarge their scale of operations. Although this finding about the optimal land size for farm households in China from previous studies is questionable (since the authors did not properly consider the role of increased capital equipment in the farm size-productivity relationship), it highlights the fact that land transactions 
and consolidation are not sustainable in the long run. It is not known, for example, how quickly land reform could shift the size of most household farms to 7-15 ha (under the current institutional arrangement) and this size, moreover, is probably still too small for farm households to apply new cropping technology (the adoption of minimum-tillage and no-tillage practices requires a minimum of 1,000-2,000 ha of land to apply the traffic control technology) and harvest the increasing returns to scale. In that sense, we can reach a caveat that land reform will facilitate land transfer and consolidation and help to enlarge the operational scale of farms, but it may not necessarily resolve the fundamental issue of small farm size.

Rather than focusing on farm size, a second body of literature (e.g. Yang et al. 2013; Zhang et al. 2017) points out that contract 'mechanised harvesting service clusters' could change the agricultural production of small farms. As the authors argue, a lack of specialisation in labour and capital in particular stages of agricultural production restricted the productivity improvement of small farms in China. To overcome this constraint, small farms could fragment their production process into different stages (as in industrial production and trade) by outsourcing certain stages-for example, those requiring specialised skills such as harvesting and sowing-provided that proper institutional arrangements were in place. The findings of Yang et al. (2013) and Zhang et al. (2017) for the first time draw attention to another option that farms could adopt to compensate for the lack of individually owned labour and capital for production efficiency improvement: cross-regional mechanisation services from related service providers. They tested their argument using a case study of Peixian in Jiangsu province.

Although the mechanism proposed in Yang et al. (2013) and Zhang et al. (2017) does not solve the main problem when agricultural production is broken into stages, and does not seem to be associated only with small farms, it provides an alternative way to think about improving the productivity and profitability of small household farms. In other words, if capital (or labour) services are divisible and separable from their ownership through the market-based contract system to fit the particular size of farms (Figure 13.17), it is no longer necessary to consolidate cultivated land to enlarge farm size (to equip better capital or labour services). In such a process, institutional innovation is essential to erase market failure caused by high transaction costs associated with dividing capital services and allocating them between farms. While outsourced mechanisation services currently account for only a small proportion of total agricultural capital services, a range of farmer cooperatives have begun providing access to capital services across China's provinces in recent years, reflecting the increasing market demand from small farms in Chinese agricultural production (Zhang et al. 2017) and its potential for future development. 


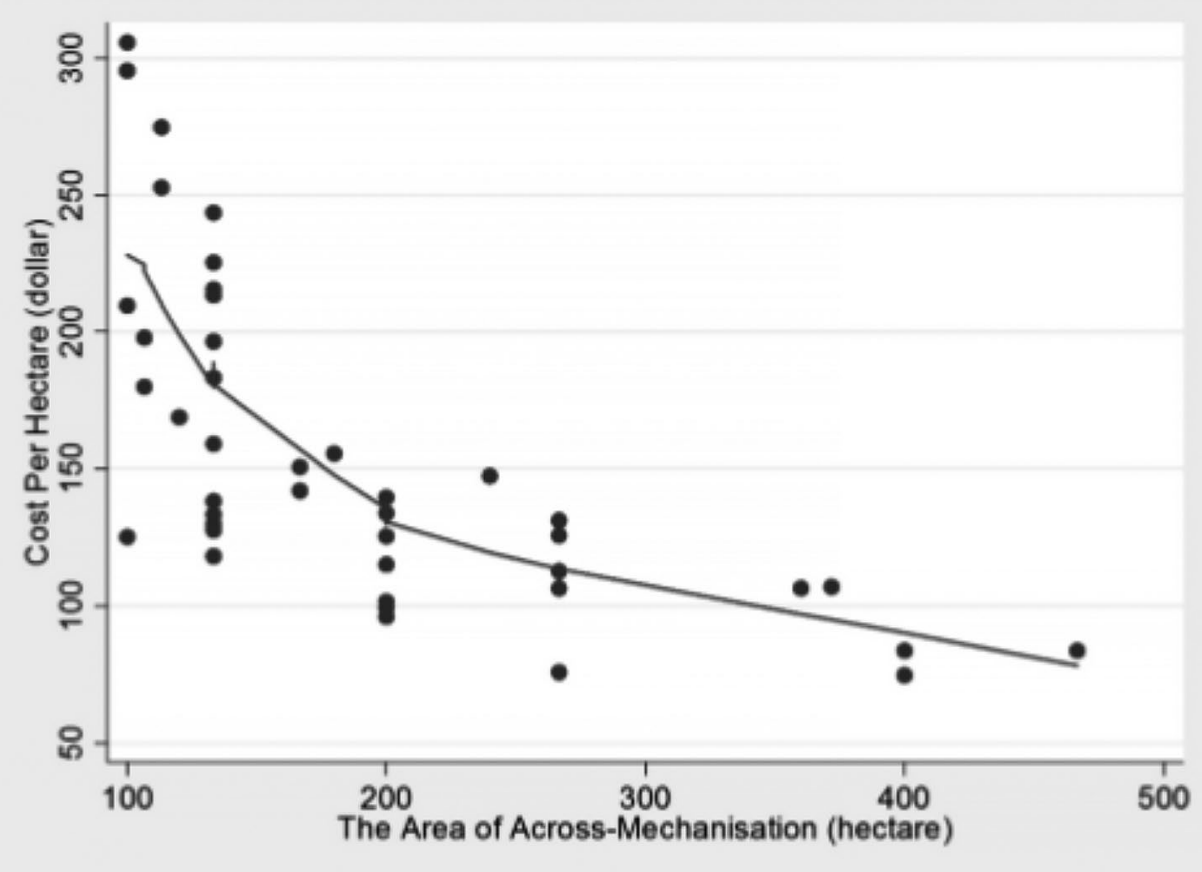

Figure 13.17 Cost per hectare and area harvested of using contracted services from combined service enterprises

Source: Zhang et al. (2017).

Finally, a third body of literature analyses the relationship between land consolidation and contract mechanisation services. While contract mechanisation services allow small farms to catch up with large farms in terms of capital equipment and thus reduce the productivity gap between farms of different size (Sheng and Chancellor 2017), they do not necessarily halt the process of farms becoming larger. In most cases, contract mechanisation services in fact help to facilitate land transfer and consolidation, since farms with superior capital equipment are more likely to efficiently manage larger areas of land. Huang and Ding (2016a) demonstrated that grain farms in China's north-east and north contracting these types of mechanisation services were around 0.12 ha larger than those not using mechanisation services between 2003 and 2013. Moreover, cooperative or company farms were more likely than household farms to preserve this relationship, when other farm and regionspecific factors were accounted for. This implies that contract mechanisation services tend to facilitate land consolidation in the Chinese grain industry. 


\section{Conclusions}

The limited size of household farms in China and in many other developing countries has long been regarded as one of the major constraints on agricultural productivity growth. As an alternative to the conventional recipe in the literature of facilitating land consolidation, this chapter points to the prospect of improving the capital-to-labour ratio of household farms through outsourcing mechanisation services to resolve the issue of small farm size. As a substitute for individual farm investment, market-based capital outsourcing would allow small household farms to access new production technologies embodied in plant and equipment in ways their larger counterparts do and also to capitalise their production process without incurring the corresponding sunk costs. Under certain conditions, the outsourcing of mechanisation services can improve the mechanisation and productivity levels of agricultural production as effectively as land consolidation, but without the huge social and economic costs. In addition, since precision farming technology would improve yields from damaged soil, previous land damage can be overcome with the superior technology available through capital outsourcing.

By outsourcing labour and power-intensive production processes (such as harvesting), some household farms in China have maintained their competitiveness despite their small size and fragmented land (Huang and Ding 2016a; Zhang et al. 2017). Although promising in theory, market-based outsourcing of mechanisation services is constrained by market friction, high transaction costs and various institutional barriers, and therefore is only in its preliminary stages in rural China. By the end of 2013, less than 1 per cent of agricultural capital equipment in Chinese agricultural production came from market-based outsourcing of mechanisation services. Asymmetric information between mechanisation service providers and potential users prevented them from meeting the increasing demand for modernised agricultural production. In turn, institutional innovation is required to reduce market transaction costs to facilitate the use of outsourced mechanisation services, as well as land consolidation reform, to deal with the issue of small farm size in agricultural production.

The Chinese experience provides some useful policy implications for developing new initiatives to improve agricultural productivity in developing countries such as India and Indonesia, where agricultural production is populated with a large share of smallholder farms. Since labour and capital services are divisible, farm size is no longer a limiting factor for scaled production if optimal use of capital equipment can be achieved through the outsourcing of mechanisation. 


\section{References}

Assuncao, J. and Ghatak, M. (2003), On the inverse relationship between farm size and productivity, Economics Letters 80(2): 189-94. doi.org/10.1016/S01651765(03)00091-0.

Babu, S. C., Huang, J., Venkatesh, P. and Zhang, Y. (2016), A comparative analysis of agricultural research and extension reforms in China and India, China Agricultural Economic Review 7(4): 541-72.

Brandt, L., Huang, J., Li, G. and Rozelle, S. (2002), Land rights in rural China: Facts, fictions and issues, The China Journal (47): 67-97. doi.org/10.2307/3182074.

Chen, Z., Huffman, W. E., and Rozelle, S. (2010), Inverse relationship between productivity and farm size: The case of China, Contemporary Economic Policy 29(4): 580-92.

Deininger, K. and Byerlee, D. (2012), The rise of large farms in land abundant countries: Do they have a future? World Development 40(4): 701-14. doi.org/10.1016/j.worlddev.2011.04.030.

Dyer, G. (1996), Output per acre and size of holding: The logic of peasant agriculture under semi-feudalism, Journal of Peasant Studies 24: 103-31. doi.org/10.1080/03066159608438632.

Food and Agriculture Organization of the United Nations (FAO) (2015), Food and Food Security Data, October, Rome: FAO.

Food and Agriculture Organization of the United Nations (FAO) (2017), Statistics, Rome: FAO. Available from: www.fao.org/statistics/en/.

Foster, A. and Rosenzweig, M. R. (2017), Input transaction costs, mechanization and mis-allocation of land, Conference paper presented to Farm Size and Productivity: A global look, Washington, DC, 2-3 February.

Fuglie, K. and Rada, N. (2015), Methodology for measuring international agricultural total factor productivity (TFP) growth, in Documentation and Methods, Washington, DC: United States Department of Agriculture Economic Research Service. Available from: www.ers.usda.gov/data-products/internationalagricultural-productivity/documentation-and-methods/.

Han, J. (2015), China: Food security and agricultural going out, in Strategy Research, [in Chinese], Beijing: China Development Press.

Hazell, P. B. (2005), Is there a future for small farms? Agricultural Economics 32(s1): 93-101. doi.org/10.1111/j.0169-5150.2004.00016.x. 
He, W., Zhu, X., Huang, Y., Zhao, X. and Ma, H. (2010), Machinery subsidy policy in China: An empirical analysis, [in Chinese], Agricultural Mechanisation Study 4: 195-8.

High Level Panel of Experts on Food Security and Nutrition (HLPE) (2013), Investing in smallholder agriculture for food security, Report, Committee on World Food Security, FAO, Rome.

Huang, J. (2013), China's agricultural development in the new era: Opportunities, [in Chinese], Bulletin of Chinese Academic Science 3: 295-300.

Huang, J. and Ding, J. (2016a), Institutional innovation and policy support to facilitate small-scale farming transformation in China, Agricultural Economics 47: 227-37. doi.org/10.1111/agec.12309.

Huang, J. and Ding, J. (2016b), An inverse u-shaped relationship between farm size and land productivity or profitability: Evidence from grain production in China, Working Paper, Center for Chinese Agricultural Policy, Peking University, Beijing.

Huang, J. and Rozelle, S. (2006), The emergence of agricultural commodity markets in China, China Economic Review 17: 266-80. doi.org/10.1016/j. chieco.2006.04.008.

Huang, J. and Rozelle, S. (2014), Agricultural R\&D and extension, in S. Fan, R. Kanbur, S.-J. Wei and X. Zhang (eds), The Oxford Companion to the Economics of China, pp. 315-19, London: Oxford University Press. doi.org/10.1093/ acprof:oso/9780199678204.003.0051.

Huang, J. and Yang, G. (2017), Understanding recent challenges and new food policy in China, Global Food Security 12(March): 119-26. doi.org/10.1016/j. gfs.2016.10.002.

Huang, J., Gao, L. and Rozelle, S. (2012), The effect of off-farm employment on the decisions of households to rent out and rent in cultivated land in China, China Agricultural Economic Review 4: 5-17. doi.org/10.1108/17561371211196748.

Huang, J., Liu, Y., Martin, W. and Rozelle, S. (2009), Changes in trade and domestic distortions affecting China's agriculture, Food Policy 34: 407-16. doi.org/10.1016/j.foodpol.2009.04.001.

Huang, J., Wu, Y., Zhi, H. and Rozelle, S. (2008), Small holder incomes, food safety and producing, and marketing China's fruit, Review of Agricultural Economics 30: 469-79. doi.org/10.1111/j.1467-9353.2008.00421.x.

International Food Policy Research Institute (IFPRI) (2015), Global Food Report, 2014-2015, Washington, DC: IFPRI. 
Key, N. (2017), Farm size and productivity growth in the United States corn belt, Conference paper presented to Farm Size and Productivity: A global look, Washington, DC, 2-3 February.

Kimura, S., Otsuka, K. Sonobe, T., Rozelle, S. (2011), Efficiency of land allocation through tenancy markets: evidence from China, Economic Development Cultural Change 59: 485-510.

Krusekopf, C. C. (2002), Diversity in land-tenure arrangements under the household responsibility system in China, China Economic Review 13(2-3): 297-312. doi.org/10.1016/s1043-951x(02)00071-8.

Kung, J. K.-S. and Liu, S. (1997), Farmers' preferences regarding ownership and land tenure in post-Mao China: Unexpected evidence from eight counties, The China Journal (38): 33-63. doi.org/10.2307/2950334.

Lipton, M. (1993), Land reform as commenced business: The evidence against stopping, World Development 21(4): 641-57. doi.org/10.1016/0305750X(93)90116-Q.

Liu, M., Xu, Z., Su, F. and Tao, R. (2012), Rural tax reform and the extractive capacity of local state in China, China Economic Review 23: 190-203.

Lu, Y., Jenkins, A., Ferrier, R. C., Bailey, M., Gordon, I. J., Song, S., Huang, J., Jia, S., Zhang, F., Liu, X., Feng, Z. and Zhang, B. (2015), Addressing China's grand challenge of achieving food security while ensuring environmental sustainability, Science Advances 1(1): e1400039. doi.org/10.1126/sciadv.1400039.

Meng, X. and Zhang, D. (2010), Labour market impact of large-scale internal migration on Chinese urban 'native' workers, IZA Discussion Paper 5288, Institute of Labor Economics, Bonn.

Ministry of Agriculture of China (MOA) (various issues), China Agriculture Yearbook, Beijing: China Statistics Press.

Ministry of Agriculture of China (MOA) (2014), The status of transferring rural household responsibility land in 2013, Rural Business Management 5: 42.

National Bureau of Statistics of China (NBS) (1978-2014), China Rural Statistical Yearbook, Beijing: China Statistics Press.

National Bureau of Statistics of China (NBS) (1985-2005), China Rural Household Survey Statistical Yearbook, Beijing: China Statistics Press.

O'Brien, K. and Li, L. (1999), The Struggle Over Village Elections: The paradox of China's post-Mao reforms, Cambridge, Mass.: Harvard University Press. 
Park, A., Jin, H., Rozelle, S. and Huang, J. (2002), Market emergence and transition: Arbitrage, transition costs, and autarky in China's grain market, American Journal of Agricultural Economics 84(1): 67-82. doi.org/10.1111/1467-8276.00243.

Pastor, R. A. and Tan, Q. (2000), The meaning of China's village elections, The China Quarterly 162: 490-512. doi.org/10.1017/S0305741000008225.

Prosterman, R., Ping, L. and Zhu, K. (2006), China's Regulatory Framework on Rural Land: A review and recommendations, Seattle: Rural Development Institute.

Sen, A. K. (1962), An aspect of Indian agriculture, Economic Weekly 14: 243-66.

Sen, A. K. (1966), Peasants and dualism with or without surplus labor, Journal of Political Economy 74: 425-50. doi.org/10.1086/259198.

Sheng, Y. and Chancellor, W. (2017), Exploring the relationship between farm size and productivity: Evidence from the Australian grain industry, ERS-USDA Working Paper, United States Department of Agriculture Economic Research Service, Washington, DC.

Sheng, Y. and Song, L. (2017), Agricultural production and food consumption in China: A long-term projection, CCAP Working Paper Series 2017, Center for Chinese Agricultural Policy, Beijing.

Sheng, Y., Davidson, A., Fuglie, K. and Zhang, D. (2016), Input substitution, productivity performance and farm size, Australian Journal of Agricultural and Resource Economics 60(3): 327-47. doi.org/10.1111/1467-8489.12136.

Tao, R. and Qin, P. (2007), How has rural tax reform affected farmers and local governance in China? China World Economy 15: 19-32. doi.org/10.1111/j.1749124X.2007.00066.x.

Yang, J., Huang, Z., Zhang, X. and Reardon, T. (2013), The rapid rise of crossregional agricultural mechanization services in China, American Journal of Agricultural Economics 95(5): 1245-51. doi.org/10.1093/ajae/aat027.

Zhang, F., Chen, X. and Vitousek, P. (2013), Chinese agriculture: An experiment for the world, Nature 497: 33-5. doi.org/10.1038/497033a.

Zhang, X., Yang, J. and Reardon, T. (2017), Mechanization outsourcing clusters and division of labor in Chinese agriculture, China Economic Review 43(April): 184-95. doi.org/10.1016/j.chieco.2017.01.012.

Zhao, X. (2015), To Reallocate or Not? Optimal Land Institutions Under Communal Tenure: Evidence from China, New Haven, Conn.: Campus Press.

Zhu, K. and Prosterman, R. (2007), Securing land rights for Chinese farmers: A leap forward for stability and growth, Development Policy Analysis No. 3, Center for Global Liberty and Prosperity, Washington, DC. 
This text is taken from China's New Sources of Economic Growth: Human Capital, Innovation and Technological Change, Volume 2, edited by Ligang Song, Ross Garnaut, Cai Fang and Lauren Johnston, published 2017 by ANU Press, The Australian National University, Canberra, Australia.

dx.doi.org/10.22459/CNSEG.07.2017.13 